\title{
ANALYSIS ON EXPORT COMPETITIVENESS AND FACTORS AFFECTING OF NATURAL RUBBER EXPORT PRICE IN INDONESIA
}

\author{
Putri Daulika ${ }^{1,2 *}$ Ke-Chung Peng ${ }^{2}$, Nuhfil Hanani ${ }^{3}$ \\ ${ }^{1}$ Program Double Degree in Faculty of Agriculture, Brawijaya University, Malang \\ ${ }^{2}$ National Pingtung University of Science and Technology, Taiwan \\ ${ }^{3}$ Faculty of Agriculture, Brawijaya University, Malang \\ *Corresponding Author’s E-mail: daulikaputri@gmail.com
}

\begin{abstract}
Rubber is one of Indonesia's leading plantation commodities that is oriented to the international market with export destination countries to several countries. Rubber provides a positive contribution to the economy because it generates foreign exchange for the country. This study aims to analyze (1) the factors that influence the price of Indonesian natural rubber exports and (2) the position of Indonesia's rubber competitiveness in comparative and international competitive advantages. This study uses time-series data is from 1995 to 2017. Data were analyzed using multiple linear regression for influence factors the price of Indonesian natural rubber exports, while to analyze the position competitiveness of Indonesian natural rubber that is by using a revealed comparative advantage (RCA), and competitive advantage by using the Trade Specialization Index approach (TSI). The results of this study show (1) the factor that significantly affects the price of Indonesia's natural rubber exports are international rubber prices, exchange rate, and domestic consumption. (2) Based on competitiveness analysis, through Revealed Comparative Advantage (RCA) indicate that the competitiveness of Indonesia's natural rubber exports on the international market has a comparative advantage seen from 1995-2017 with an average value of RCA> 1 which is equal to 1.01. While the competitive advantage for the competitiveness of Indonesian rubber exports is at the maturation stage. This condition occurs because the value of the Trade Specialization Index (TSI) approaches 1, which is 0.98 .
\end{abstract}

Keywords: Competitiveness, export prices, Indonesian natural rubber, RCA, TSI

http://dx.doi.org/10.21776/ub.agrise.2020.020.1.6

Received 23 July 2019

Accepted 10 January 2020

Available online 31 January 2020

\section{INTRODUCTION}

Indonesia as a developing country adheres to an open economic system where international economic traffic is very important in the economy and national development. Economic development requires that the welfare of the population must increase, and one measure of the increase in welfare is economic growth [1]. The growth of industries that use rubber raw materials, the natural rubber market in the world will be increasingly open. This situation provides an opportunity for Indonesia as a country producing natural rubber to increase exports of natural rubber on the world market. Therefore, efforts to increase production along with competitiveness should be done. This effort is not easy because Indonesian natural rubber producers are dominated by farmers with limited socio-economicconditions.

Indonesia is a country with abundant natural resource not only in the oil and gas sector but also in the agricultural sector. This is blessed with a great climate for agriculture, fantastically fertile volcanic soil, an overflow of water, plenty of arable lands and no lack of working hands. Agricultural 
takes an important role in Indonesia economic growth. The main agricultural products export which can increase national income are palm oil, rubber, coffee, cocoa, white pepper, and shrimp. One of these products is natural rubber that the most important commercial crops after palm oil [2].

Rubber is one of the plantation commodities which plays an important role as a foreign exchange earner because it is one of the non-oil and gas export commodities that makes a significant contribution. The role of rubber commodities on Indonesian exports cannot be said to be small, given the export of rubber commodities is one of the main export commodities after palm oil. Aside from being a source of state income, opening up employment opportunities, rubber is also believed to be a commodity that drives the growth of new centers in the plantation area. In addition, rubber commodities can also help to preserve the environment and as a biological resource.

Indonesian rubber is expected to be able to compete with rubber from other countries going forward. If Indonesian rubber has competitiveness in the international market, it is expected that more countries will buy rubber from Indonesia and entrepreneurs will be even more enthusiastic to produce better quality rubber with lower production costs in order to earn profits and be able to sustain their production. Based on demand and supply factors, rubber prices should remain high because the demand level tends to increase sharply while offers tend to remain. But in reality, the price of rubber exports tends to fluctuate. This shows that many other factors also influence the price of rubber exports.

\section{Literature Review}

Fernando (2009) the purpose of this study is measuring the competitiveness of Indonesian corn exports in the Malaysian market and analyzing factors that affect Indonesian corn exports in the Malaysian market. Data used are data on corn export time series and factors that influenced them in 1990- 2008. The method used to measure the competitiveness of Indonesian corn exports is by using the Revealed Comparative Advantage (RCA) method and for analyzing the factors that influence Indonesian corn exports during pre and after the economic crisis using a multiple regression analysis models. The results of this study show, at the time before the economic crisis in 1990 to 1998 [4].
Indonesian maize is traded on the Malaysian market with types corn 1005 has a comparative advantage or competitiveness in 1990, 1991, 1992, 1993, 1995, and 1998 with each the acquisition of RCA values was 6,427, 1,050, 5,314, 1,803 and 7,934 . The comparative advantage of corn obtained is based on increasing the value of Indonesia's corn exports in the Malaysian market and declining the value of world corn exports in the Malaysian market. At the time after the economic crisis in 1999 to 2008, Indonesian maize is traded on the Malaysian market with types corn 1005 has a comparative advantage or only competitiveness in 1999 with the acquisition of an RCA value of 1,065. However, in 2007 the RCA index value of 13,352 showed that Indonesian corn has increased market share in Malaysia. The variables used in the study have a real influence against Indonesian corn exports in the Malaysian market before the economic crisis. However, the variables are in accordance with the hypothesis is variable production volume, domestic corn price, import volume Indonesian corn, and the rupiah exchange rate against the US \$. After the economic crisis in 1999 to 2008, variables used in research that does not have a significant effect the Indonesian corn export in the Malaysian market is the exchange rate rupiah against US \$, thus affecting the decline in corn exports Indonesia in the Malaysian market.

Ananto (2010) in this study, the method is used is multiple correlation analysis, Revealed Comparative Advantage (RCA) and Trade Specialization Index (ISP). Analysis results in RCA from 2004-2008> 1 (one), this means that Indonesia has a performance good exports, can also be said to have advantages comparative, then the results of the ISP analysis show that Indonesia is in the international market is an exporter of palm oil, because it has ISP values for palm oil commodities> 0 (zero), so Indonesia tends to export more than import.

Kautsar (2014) was also researching about factors affecting export price of Indonesia ${ }^{\text {ee }}$ s natural rubber. The purposes of this study are to describe the condition the export price of Indonesian natural rubber and to analyze the factors affecting the export price of Indonesian natural rubber. This study uses panel data regression in 2002-2012. The results of this research indicate that world prices, export tariff, exchange rate, domestic consumption, export volume, and global crisis significantly 
influence the export price of Indonesian natural rubber.

\section{RESEARCH METHODS}

This research was conducted from April 2019 to June 2019. The place for the implementation of this research was carried out in Indonesia. The commodity of this study is Natural Rubber.

\section{Method of collecting data}

The data used in this study are secondary data which are time-series data in the form of annual data starting from 1995 to 2017 . The data collected for this study includes data on rubber prices on international markets, the volume and value of exports, the volume and value of imported rubber, and the prices of Indonesian rubber exports, the rupiah exchange rate against the dollar and domestic consumption, as well as from various books and journals and other related sources that support this research.

\section{Data Analysis Method}

\section{Regression Analysis}

The first objective of this research is to find out the factors that influence the price of Indonesian natural rubber exports, used a multiple regression analysis tool. In summary, the Indonesian rubber export price regression model used in this study is as follows:

Where:

$$
\mathrm{Y}=\beta 0+\beta 1 \mathrm{X} 1+\beta 2 \mathrm{X} 2+\beta 3 \mathrm{X} 3+\mathrm{ei}
$$

$\mathrm{Y}=$ Indonesian rubber export price ( $\mathrm{Rp} /$ ton)

$\mathrm{X} 1=$ Rubber prices in international markets (US \$ / ton)

$\mathrm{X} 2$ = Rupiah to dollar exchange rate (Rp / US \$)

$\mathrm{X} 3=$ Domestic Consumption (ton)

ei $=$ Error

Based on the results of model identification, estimating the model is done by multiple linear regression methods, data processing is done by STATA. This study uses statistical tests namely RSquared Test, F-Test, T-Test. The coefficient of determination (R2) essentially measures how far the model's ability to explain the variation of the dependent variable. The F-Test is a test statistic used to find out how the influence of independent variables on the non-independent variables as a whole the first step to do the t-test is to write the test hypothesis. The t-test is a test statistic used to measure the parameters significantly individually and is also called a partial significance test because it looks at the significance of each variable contained in the model. The t-test in this study is used to determine the effect of each explanatory factor on Indonesia's television export supply.

\section{Competitiveness Analysis}

The competitiveness of a country in a product or commodity can be estimated through comparative advantage and competitive advantage. Revealed Comparative Advantage (RCA) analysis is a method for analyzing the comparative advantage. Whereas to identify a product or commodity that has a competitive and dynamic advantage (rapid growth) in a country, an analysis of the Trade Specialization Index (TSI) is used [7].

One way to measure comparative advantage is to use the Revealed Comparative Advantage Index, which compares the export market share of a particular sector in a region with a specific sector market share [8].

The competitive advantage of a product can be measured using the analysis of the Trade Specialization Index (TSI). The Trade Specialization Index (TSI) is a comparison between the difference in export value and the import value of a region compared to the total export value and import value of the region, or in other words, TSI is a comparison between the net trade value difference with the total trade value of a region. The TSI index can also be used to analyze the process of the industrialization stage and the development of the trading pattern of these commodities.

\section{RESULTS AND DISCUSSION}

\section{Analysis of factors affecting the price of Indonesia's natural rubber exports.}

This section is the purpose of this study. This study aims to see how the factors (international rubber prices, the rupiah exchange rate against the dollar, and domestic consumption) affect the price of Indonesian rubber exports. Table 1 is the result of data processing. Data processing is done through the Stata program. 
Table 1: Regression Results

\begin{tabular}{cccccc}
\hline $\begin{array}{c}\text { Rubber } \\
\text { Export Prices }\end{array}$ & Coefficient & Std. Err. & $\mathrm{P}>|\mathrm{t}|$ & \multicolumn{3}{c}{$[95 \%$ Confidence Interval] } \\
\hline IP & .5952858 & .0465217 & $0.000^{*}$ & .4979147 & .6926569 \\
ER & -.0549465 & .0173753 & $0.005^{*}$ & -.0913134 & -.0185797 \\
DC & .0123412 & .0055424 & $0.038^{*}$ & .0007409 & .0239416 \\
Constant & 661.3653 & 142.8514 & 0.000 & 362.3946 & 960.336 \\
\hline
\end{tabular}

Source: Source: Processing data stata program, 2019. •: Significance level $0.05(5 \%)$

Based on the test results table above, the regression model results are:

$\mathrm{Y}=661.36+0.5952 \mathrm{X} 1-0.0549 \mathrm{X} 2+0.0123 \mathrm{X} 3+\mathrm{e}$

The amount of the international price value (X1) is 0.5952 which can be stated as worth positive, the value of the rupiah exchange rate against the United States dollar (X2) is equal 0.0549 is negative, and the value of domestic consumption (X3) is equal to 0.0123 is positive. From the results of multiple linear regression that have been presented, then the results of the model analysis show that international rubber prices, the exchange rate of the rupiah against the dollar and domestic consumption affect the price of Indonesia's natural rubber exports significantly.

\section{$R$-Squared Test and F Test}

The use of the coefficient of determination is to measure how much the ability of the independent variable to explain the dependent variable in the model. Estimation results show the value of R2 in the model has a value of 0.898 or $89.8 \%$, which means that there is a change in the independent variable (international rubber prices, rupiah exchange rate against the dollar, and domestic consumption) in this model can explain $89.8 \%$ from the dependent variable (the price of Indonesian rubber exports), while the remaining $10.2 \%$ is explained by other factors outside the model not used in this study.

The $F$ test is used to see whether the independent variables together explain the dependent variable. In statistical testing with the Stata program, it was found that the significance of $\mathrm{F}$ in this study was 55.79. Where $\mathrm{F}$ count $>\mathrm{F}$ table is 55.79> 3.12. This means that the five independent variables used (international rubber prices, the rupiah exchange rate against the dollar, and domestic consumption) can be concluded to influence the price of rubber exports.

\section{T-test}

Partial significance test (t-test) has a purpose to test the effect of each independent variable on the prices of Indonesian natural rubber exports from 1995-2017.

Table 2. Results of Partial Hypothesis Test (t-test) on Y

\begin{tabular}{llcc}
\hline \multicolumn{1}{c}{ Variable } & Coef & Std. error & $\mathrm{t}$ \\
\hline Constant & 661.3653 & 142.8415 & 4.63 \\
International rubber prices (X1) & .5952858 & .0465217 & 12.80 \\
Exchange rate (X2) & -.0549465 & .0173753 & -3.16 \\
Domestic Consumption (X3) & .0123412 & .0055424 & 2.23 \\
\hline
\end{tabular}

Sources: processed from stata, 2019.

Based on the table above, it can be seen that the calculated $\mathrm{t}$ value for international rubber prices (X1) is equal to 12.80 . This value will be compared with the value of the table in the distribution $\mathrm{t}$ table, with $\alpha=0.05, \mathrm{df}=19$, for the two-sided test, the $t$ table value is 1.72 . It is known that $t$ count for $\mathrm{X} 1(12.80)>\mathrm{t}$-table, then Ho is rejected, meaning international rubber prices (X1) partially have a significant effect on the price of Indonesian rubber exports. T-count for X2 (-3.16)> t-table, then Ho is rejected, meaning that the exchange rate of the rupiah against the dollar (X2) partially has a significant effect on the price of Indonesian rubber exports. T-count for X3 (2.23)> t table, then Ho is rejected, meaning domestic consumption (X3) partially has a significant effect on the price of Indonesian rubber exports. 


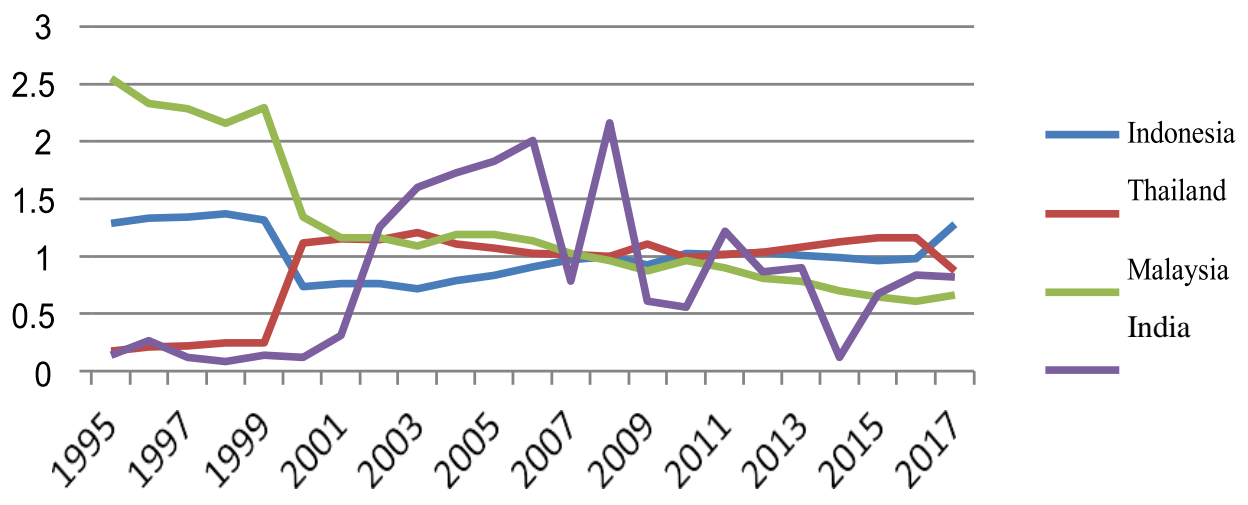

Figure 1: Revealed Comparative Advantage (RCA) of Indonesian Natural Rubber

\section{Indonesia}

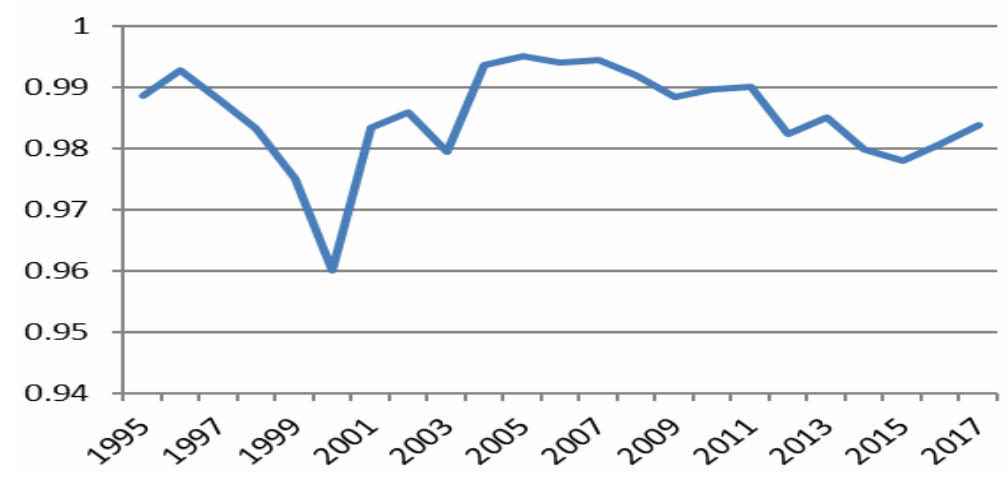

Figure 2: Trade Specialization Index (TSI) of Indonesian Natural Rubber

Based on Figure 1 shows that the value of RCA Indonesia has an average of more than 1 export value of natural rubber on the world market. RCA values ranged from 0.7 to 1.3 during 1995 2017. The highest value was in 1998 and declined in 2003.

Based on the results of calculations, it was found that the value of RCA Indonesia in 1995-2017, as one of the largest rubber producers in the world was equal to 1.01. This number is worth more than one, which means that Indonesia has a comparative advantage over natural rubber. Indonesia must continue to maintain and enlarge the comparative advantage it possesses. Indonesia is ranked second for the value of rubber exports in the international market after Thailand. The average value of RCA Thailand and India in 1995-2017 did not reach one, so the two countries did not have comparative advantages. While Indonesia and Malaysia have an average value of RCA more than one, namely 1.01 and 1.25 , which means that both countries have comparative competitiveness.

\section{Trade Spesialisation Index (TSI) Analysis}

The position analysis of Indonesian rubber trade can be analyzed using the Trade Specialization Index (TSI) method. This index is used to see whether a country tends to be an exporter or importer country for certain types of products. In this study, the country in question is the State of Indonesia. In this study the commodities studied were rubber.

In figure 2 above, it can be seen that the TSI value of Indonesia's natural rubber exports from the smallest to the largest is 0.9600 and 0.9950 . The value of the Trade Specialization Index is between -1 and +1 . If the value of the Trade Specialization Index is positive $(0<\mathrm{TSI} \leq 1)$, then the relevant commodity has strong competitiveness or the country tends to be the exporter of the commodity. Conversely, competitiveness is low or tends to be an importer, if the value is negative $(-1 \leq \mathrm{TSI}<0)$. Based on the value of the Specialization Index of natural rubber, it can be concluded that Indonesian 
natural rubber is a position of competitiveness seen from the product cycle which is the maturation stage. This condition occurs because the value of the Trade Specialization Index of natural rubber produced by Indonesia has an average value of the Trade Specialization Index from 1995-2017 which is close to 1 which is equal to 0.98 . The State of Indonesia from 1995 to 2017, calculated to have a TSI value of almost 1 . Where the products produced are included in the category of products that have very strong competitiveness. Indonesia gets a TSI score of almost 1, this can happen because Indonesian rubber exports tend to increase. TSI values fluctuate but still close to 1 .

\section{CONCLUSION}

The results of the model analysis show that international rubber prices, the exchange rate of the rupiah against the dollar, and domestic consumption significantly affect the price of Indonesia's natural rubber exports. International rubber prices, and domestic consumption have a positive relationship with Indonesia's natural rubber export prices. While the exchange rate of the rupiah against the dollar has a negative relationship with the export prices of Indonesia's natural rubber.

Based on competitiveness analysis, through Revealed Comparative Advantage (RCA) analysis shows that Indonesian rubber in the international market has a comparative advantage or strong competitiveness with RCA value $>1$ which is equal to 1.01 . Whereas the competitive advantage is seen at the maturation stage. This condition occurs because the value of the Specialized Trade Index (TSI) of natural rubber produced by Indonesia has a Trade Specialization Index value close to 1 which is equal to 0.98 .

\section{ACKNOWLEDGEMENTS}

Alhamdulillah, I'm grateful to Allah for given easiness and smoothness for me to complete this study. I wish to express appreciation to my advisor in National Pingtung University of Science and Technology (NPUST), Dr. Ke - Chung Peng, who has provided guidance and learning materials in this research. Not forgotten, my appreciation to Prof. Dr. Ir. Nuhfil Hanani AR., MS as my advisor in University of Brawijaya (UB) and as the Rector of Brawijaya University who has patiently provided support, information, and advice for my research topic.

I want to say an appreciation for the Dean of Department of International Agribusiness Management NPUST, Dr. Wen-Chi Huang, and the Chairman of Double Degree Program UB, Prof. Liliek Sulistyowati. And also, I would like to give appreciation for Bureau of Foreign Partnership (BKLN) of DIKTI Indonesia, which has facilitated the learning process in Taiwan and I would like to give appreciation to all office staff of International College for their hands.

\section{REFERENCES}

Arifin. 2005. Increased Production and Competitiveness of Rubber Based AgroIndustry Using the Green Productivity Concept.

Directorate General of Plantation. 2017. Economic Profile and Rubber Statistics.

Hendratno EH. 2010. Analysis of demand for Indonesian natural rubber exports in China [thesis]. Bogor (ID): Bogor Agricultural Institute

Fernando. 2009. Competitiveness Analysis and Factors Affect Indonesian Corn Exports on the Malaysian Market Pre and Post the Economic Crisis. Journal of Economics. Bogor Agricultural Institute. Bogor

Ananto. 2010. Export Analysis and competitiveness of Indonesian CPO on The Market International. Journal of Economics. Bogor Agricultural Institute. Bogor.

Kautsar. 2014. Factors affecting the price of Indonesia's natural rubber exports. Journal of Economics. Bogor Agricultural Institute. Bogor.

Firdaus, M and Ariyoso. 2010. Market Integrity and Factors Affecting Indonesian Cocoa Prices. Journal of Economics and Development Policy. Bogor Agricultural Institute. Bogor.

Anggit Rashid. 2012. Analysis of Indonesia's Competitiveness of Crude Palm Oil (CPO) in the International Market. Journal. SEPA : Vol. 9. No. 1:125-133.

Tambunan, Tulus T.H. 2003. Development of the Agricultural Sector in Indonesia, Some Important Issues. Jakarta: Ghalia Indonesia. 